\title{
Investigating the Causal Relationship between Inflation and Trade Openness using Toda-Yamamoto Approach: Evidence from Zambia
}

\author{
Chibvalo Zombe ${ }^{1}$ \\ Lincoln Daka ${ }^{1}$ \\ Christopher Phiri ${ }^{1}$ \\ Oliver Kaonga ${ }^{2}$ \\ Francis Chibwe ${ }^{3}$ \\ Venkatesh Seshamani $^{2}$ \\ ${ }^{1}$ Department of Economics, Copperbelt University, Kitwe, Zambia \\ ${ }^{2}$ Department of Economics, University of Zambia, Lusaka, Zambia \\ ${ }^{3}$ Rural Electrification Authority, Lusaka, Zambia
}

Doi: $10.1515 / m j s s-2017-0054$

\section{Abstract}

The paper examines whether a significant relationship exists between inflation and trade openness in Zambia over the period 1985 to 2015. We use the Toda-Yamamoto approach to Granger causality to test for a causal relationship between inflation and trade openness. The results establish a bi-directional causality between inflation and trade openness. Further, there exists a positive relationship between inflation and trade openness in Zambia. Our findings stress the importance for central banks to understand the consequences of international trade for domestic inflation.

Keywords: inflation, trade openness, Toda-Yamamoto approach to Granger causality

\section{Introduction}

For many development theorists, international trade is a key variable in the development process of a country. It is believed that increased trade enhances export earnings, promotes industrialization, and encourages diversification of the economy (Ndulo and Mudenda, 2004). This view has been supported by the endogenous growth theory that is typically based on models of endogenous technological change. The theory shows that trade openness provides access to imported inputs embodying new technology, raises the returns on innovations of domestic producers by increasing the effective size of the market they face, and facilitates a country's specialization in researchintensive production. Thus, a more open economy faces more competition from its trading partners that stimulates productivity, and this kindles economic growth (Romer, 1989).

Based on the benefits of international trade highlighted above, many developing countries embarked on an ambitious program to liberalize their economies in the 1980s. As a result, unweighted tariffs reduced in developing countries from 34\% between 1980 and 1983 to $15 \%$ between 1997 and 1999 (United Nations Conference on Trade and Development, 2004). Although the outcomes of the liberalization program on individual economies have been mixed (depending on the nature, structure, and degree of openness of the economy), a common observation during 
the 1990s was the fall in average inflation rates globally. Average inflation in industrialized economies between 1982 and 1991 was $4.9 \%$ but reduced to $0.8 \%$ by the end of 1999 . More remarkably, average inflation in developing countries dropped from $45.1 \%$ between 1982 and 1991 to $6.9 \%$ in 1999 (International Monetary Fund, 2000). Whether these two phenomena are related is still a debate in economic literature.

\section{Literature Review}

The earliest discussion concerning the relationship between trade openness and inflation can be traced back to Triffin and Grudel (1962) who examined the economic growth of six European countries and found that more open economies tended to experience lower price inflation. Their explanation was that openness served as a 'safety valve' since the domestic inflationary pressure, created by monetary authorities, had more effect on the balance of payments than on inflation in open economies. Similarly, lyoha (1973) found a negative relation between inflation and trade openness among 33 developing countries. Romer (1993), using Rogoff's (1985) model, studied 114 economies over the period 1973 to 1988 and found a strong robust negative relationship between the two variables - this has come to be known as Romer's hypothesis. His explanation was that monetary authorities in open economies have fewer incentives to conduct 'surprise' monetary expansion. This is because 'surprise' monetary expansion is responsible for the real exchange rate depreciation; whose negative effects are greater in open economies. Thus, if 'surprise' monetary expansion is an important determinant of inflation, then monetary authorities in open economies will have less incentives to undertake it, and the result will be lower average rates of inflation.

After Romer's (1993) paper the relationship between inflation and trade openness has been widely debated in literature. Studies such as Lane (1997), Yanikkaya (2003), Kim and Beladi (2005), and Nunziataz and Bowdler (2006) have all confirmed Romer's hypothesis. Furthermore, Romer's hypothesis has support from the new growth theory which reveals that trade openness is likely to affect inflation through its effect on output (Jin, 2000). Ashra (2002) also notes that the link between the two could operate through increased efficiency, which is likely to reduce costs through changes in the composition of inputs procured domestically and internationally, better allocation of resources, increased capacity utilization, and a rise in foreign investment which could stimulate output growth and ease pressure on prices.

However, other studies have challenged Romer's hypothesis. For example, Terra (1998) claims that the negative correlation was only evident in severely indebted countries during the 1980s crisis period. Ashra (2002), using a panel data framework found a positive relationship between trade openness and inflation for Bangladesh. Others who have found a positive relationship between inflation and openness include Zakaria (2010) and Munir and Kiani (2011). Temple (2002) using trade openness and the slope of the Phillips curve provide little support for the theoretical prediction of a correlation between openness and standard measures of the outputinflation trade-off.

Some studies have also shown that the relationship between inflation and trade openness may be non-existent. For example, Bleaney (1999) noted that the negative relationship between openness and inflation is weak as the link disappeared in the 1990s. Binici et al (2012) found an insignificant relationship between inflation and openness among Organization for Economic Cooperation and Development (OECD) economies, a result Munir et al (2015) also found in selected Asian countries.

Despite the importance of the relationship between trade openness and inflation in literature, studies on this subject have remained scanty and evidence to confirm or refute Romer's (1993) hypothesis is still inconclusive. Moreover, the majority of studies done so far have been at multicountry level rather than country specific. Such multi-country studies do not allow for country specific dynamics of the relationship among economic variables.

Zambia embarked on a trade liberalization program in the early 1990s. The results of this program are still debatable. On the one hand, some have praised the program for the positive economic outlook observed from the early 2000s. On the other hand, others have blamed the program for the widespread poverty level in the country. In spite of this debate, one thing is for sure: 
inflation rate declined from $106 \%$ in 1990 to $18 \%$ in 1999 to $14 \%$ in 2010 and to $6.6 \%$ in 2015 . However, there has not been any study conducted to determine the causal relationship between inflation and trade openness in Zambia. This study seeks to fill this gap. It seeks to answer the fundamental question: should monetary authorities in Zambia base their inflation-targeting policy on Romer's hypothesis?

\section{Zambia: Brief Historical Background}

At independence in 1964, Zambia was one of the richest economies in Sub-Saharan Africa. Its average annual GDP growth rate between 1965 and 1974 was 3.9\%, average GDP per capita was US\$ 1595 , inflation rate was $8.9 \%$, and the current account surplus stood at $3 \%$ of GDP (see Table 1 below). The mainstay of the economy was the production and exportation of copper that accounted for over $90 \%$ of foreign exchange earnings and $40 \%$ of gross domestic product (GDP) in 1964.

Table 1: Selected macroeconomic indicators for Zambia 1965 - 2015

\begin{tabular}{lccccccc}
\hline & \multicolumn{3}{c}{$1965-1974$} & $1975-1984$ & $1985-1990$ & $1991-1999$ & 2000-2009 2010- 2015 2015 \\
GDP growth (annual \%) & 3.9 & 0.1 & 1.6 & 1.5 & 6.8 & 6.0 & 2.9 \\
GDP per capita (constant 2010 US\$) & 1,595 & 1,317 & 1,076 & 938 & 1,109 & 1,551 & 1,607 \\
CPI (annual \%) & 8.9 & 10.6 & 67.8 & 66.4 & 17.5 & 9 & 6.7 \\
Current account (\% GDP) & 3 & -11 & -13.4 & -10.8 & -7 & 2 & -3.6 \\
\hline \hline
\end{tabular}

Source: World Bank's World Development Indicators (WDI) and Zambia's Central Statistical Office

During the first four years of independence, Zambia pursued a free market-oriented policy framework with little public sector participation. However, from 1968 onwards, the government introduced state-led import substituting industrialization strategy. This entailed excessive control of the economy through nationalization and protectionist trade policy. The nationalization program saw government's stake in foreign companies rise from $42 \%$ in 1964 to over $80 \%$ by 1970 . During this period, the government's strategy seemed to be working owing to the high copper prices on the world market. The revenue from copper enabled the government to develop infrastructure such as roads, schools, and other social amenities, as well as support its socialist agenda.

However, in 1973, the increase in the oil prices by about $400 \%$ and a fall in the copper prices created problems for the country. The foreign exchange earnings from copper slumped and the government was now failing to sustain its socialist agenda. Seshamani (1992) notes that Zambia's foreign reserves dwindled as she tried to cover her oil import bills. The government responded to this situation by contracting debt and by further increasing its tariffs that varied between $0 \%$ for intermediate goods and $150 \%$ for final goods. Essential consumer goods and some capital and heavy intermediate inputs had lower tariffs while consumer durables had higher nominal tariffs of between $50 \%$ and $100 \%$. Furthermore, import bans were introduced on commodities while foreign exchange was administratively allocated to firms as a way of controlling and protecting the domestic industry (Mudenda, 2009). These interventions did not help as GDP growth declined to $0.1 \%$, GDP per capita fell to US\$1,317, inflation rate rose to $10.6 \%$, and current account deficit stood at $11 \%$ of GDP between 1975 and 1984 (see Table 1).

The government, therefore, adopted structural and stabilization policies, known as the Economic Reform Program (ERP), developed by the International Monetary Fund (IMF) and World Bank between 1983 and 1986. The ERP's main focus was to enable government generate revenue so that it does not engage in deficit financing. In this regard, growth in non-traditional exports was to be promoted in order to reduce the reliance on copper. To promote exports, it was recommended that the Kwacha, Zambia's local currency, be devalued progressively and the auctioning system be introduced as a way of allocating foreign exchange. Further, efficiency in the allocation of both foreign and domestic resources was to be promoted. Domestic savings were to be mobilized in order to curb overreliance on foreign investment. Interest rates were to be decontrolled in order to 
promote savings and efficiency in the allocation of resources. Abolition of price controls was to be done to give the manufacturers incentives to reverse the trend of food shortages. In the course of implementing these reforms, inflation rose sharply from $9.1 \%$ in 1982 to $55.9 \%$ in 1986 . Some argue that the rise in inflation was due to the introduction of the auction system while others believe it was due to price decontrols.

The rise in the inflation rate sparked social unrest in the economy. As a result, in 1987, the government abandoned the IMF and World Bank (WB) reform packages to pursue the New Growth Recovery Program (NGRP) whose theme was "growth from own resources" (Seshamani, 1992). However, faced with a decline in copper production, mounting debt, and broad based freeze on multilateral and bilateral aid, the government, in 1989, had to go back to the IMF/WB program (Ibid, 1992). The implementation of IMF/WB reform policies brought about devastating effects on the economy with the inflation rate rising to $119.1 \%$ in 1989 . Therefore, due to mounting pressure from the citizenry, the government once again abandoned the IMF/WB program in 1991.

In 1992, the newly elected government of the Movement for Multi-Party Democracy (MMD) led by Dr. F.T.J. Chiluba with support from many stakeholders hastily adopted the IMF/WB economic reforms enshrined in the Structural Adjustment Programs (SAPs). The reforms included removing exchange controls, reducing import duties, eliminating import and export license requirements, abolishing export bans and introducing a number of export incentives, removing subsidies, and decontrolling prices (Mudenda, 2009). Subsequently, the inflation rate in the economy rose from $99.3 \%$ in 1991 to $162.3 \%$ in 1992 and then to $185.9 \%$ in 1993 . It only fell to $61.9 \%$ in 1994 . By 1997, the government managed to reduce inflation to $24.9 \%$ perhaps the structural and liberalization policies were beginning to bear fruit (see Table 1). During the mid-2000s, the copper prices started to rise causing the exchange rate to appreciate significantly. Furthermore, after meeting certain performance criteria, Zambia qualified for the Highly Indebted Poor Countries (HIPC) debt relief initiative in the year 2005. This offered some solution to Zambia's debt situation reducing its debt by a total of US\$2.7 billion, resulting in a saving of US\$233million in debt service obligations between 2000 and 2007 (World Bank, 2008). These improvements were reflected in the reduction of the inflation rate to $18.3 \%$ in 2005. In April 2006, inflation rate was recorded at $9.4 \%$, the first single digit rate recorded in 30 years.

It is in the context of the above historical developments that this study looks at the relationship between trade openness and inflation in Zambia

\section{Methodology}

In this study, we use the Toda-Yamamoto approach to Granger causality developed by Toda and Yamamoto (1995) ${ }^{1}$ to test for causality between inflation and trade openness. It is an augmented Granger causality test. This procedure uses a modified Wald test for restrictions on the parameters of the vector autoregressive VAR (p) model. The test has an asymptotic Chi-squared distribution with $p$ degrees of freedom in the limit when a VAR $(p+d m a x)$ is estimated (where dmax is the maximal order of integration for the series in the system). The main merit of the Toda-Yamamoto procedure is that it can be used irrespective of whether the time series in the system are integrated of different orders or non-cointegrated or both. The procedure can be used in cases where the order of integration of one or more variables is higher than one - a case most conventional procedures such as autoregressive distributed lag models (ARDL), vector error correction models (VECMs), and VARs do not incorporate. The procedure has the following steps:

\subsection{Step 1: Determining the order of integration}

To determine the maximal order of integration ( $d$ max), we employ the Augmented Dickey-Fuller (1981) (ADF) and the Phillips-Perron (1988) (PP) unit root tests whose null hypothesis is the presence of a unit root. However, one needs to consider structural changes when dealing with time series data because structural changes and unit roots are closely related; (Perron, 1989). In

\footnotetext{
${ }^{1}$ For a detailed exposition of the Toda-Yamamoto procedure, see Umar and Dahalan (2015).
} 
addition, conventional unit root tests such as the ADF and PP are biased toward accepting a false unit root null hypothesis when the data are stationary with a structural break.

Certainly in the Zambian case, over the long period of our study, structural breaks would have occurred as the economy swung between controlled and liberalized regimes, and the most notable break would have occurred after 1992 when there was a rapid and radical shift from controls to liberalization.

There are several unit root tests devised to accommodate structural breaks such as the Banerjee, Lumsdiane and Stock test (1992), the Zivot and Andrews test (1992) and the Perron and Vogelsang (PV) test (1992). This study employs the PV test. This test consist of a class of test statistics that allow for two different forms of structural breaks - the additive outlier (AO) and innovational outlier (IO) models. The AO model allows for a sudden change in mean (crash model) while the 10 model allows for more gradual changes. According Perron and Vogelsang, these tests are based on the minimal value of t-statistics on the sum of the autoregressive coefficients over all possible breakpoints in the appropriate autoregression.

\subsection{Step 2: Determining the optimal lag length $(p)$ of the VAR}

Before determining the optimal lag-length $(p)$, this study uses the Bai and Bai-Perron approach to structural break testing developed by Bai (1997) and Bai and Perron (1998, 2003a) to determine the exact date(s) of the structural break(s) in the model. The structural break or breaks determined are then incorporated when determining the optimal lag length $(p)$ of VAR model. The optimal laglength is determined by first estimating the VAR in levels and then using the well-known information criteria such as the Akaike information criterion (AIC), and Schwarz information criterion (SC) among others. The VAR estimated in this section is then subjected to diagnostic tests; namely, normality of residuals, serial correlation, and model stability.

\subsection{Step 3: Applying the modified Wald procedure to the VAR ( $k)$}

After determining the optimal lag length in step 2, the $p$ lags, we estimate a VAR(k), where $k=p+$ $d \max$. To conduct the Toda -Yamamoto procedure based on Granger causality, the following $\operatorname{VAR}(\mathrm{k})$ model is used:

$$
\begin{array}{lll}
\text { infl }_{t}=\alpha_{1}+\sum_{i=1}^{p+d} \beta_{1 i} \text { infl }_{t-i}+\sum_{j=1}^{p+d} \gamma_{1 j} \text { open }_{t-j}+\sum_{n=1}^{p+d} \psi_{1 n} g d p p c_{t-n}+\sum_{q=1}^{p+d} \phi_{1 n} m s_{t-q}+\lambda_{1} D+\epsilon_{1 t} & 1 \\
\text { open }_{t}=\alpha_{2}+\sum_{i=1}^{p+d} \beta_{2 i} \text { open }_{t-i}+\sum_{j=1}^{p+d} \gamma_{2 j} \text { infl }_{t-j}+\sum_{n=1}^{p+d} \psi_{2 n} \text { gdppc }_{t-n}+\sum_{n=1}^{p+d} \phi_{2 q} m s_{t-q}+\lambda_{2} D+\epsilon_{2 t} & 2 \\
\text { gdppc }_{t}=\alpha_{3}+\sum_{i=1}^{p+d} \beta_{3 i} \text { gdppc }_{t-i}+\sum_{j=1}^{p+d} \gamma_{3 j} \text { open }_{t-j}+\sum_{n=1}^{p+d} \psi_{3 n} \text { infl }_{t-n}+\sum_{n=1}^{p+d} \phi_{3 q} m s_{t-q}+\lambda_{3} D+\epsilon_{3 t} & 3 \\
\text { ms }_{t}=\alpha_{4}+\sum_{i=1}^{p+d} \beta_{4 i} m s_{t-i}+\sum_{j=1}^{p+d} \gamma_{4 j} \text { open }_{t-j}+\sum_{n=1}^{p+d} \psi_{4 n} \text { infl } l_{t-n}+\sum_{n=1}^{p+d} \phi_{4 q} m s_{t-q}+\lambda_{4} D+\epsilon_{3 t} & 4
\end{array}
$$

Where

infl $l_{t}$ is inflation measured by the natural log of consumer price index (CPI);

open $_{t}$ is trade openness measured by the natural log of the ratio of the sum of exports and imports to (GDP);

$g d p p c_{t}$ is economic growth measured by the natural log of GDP per capita;

$m s_{t}$ is money supply measured by natural log of broad money supply

$\lambda_{i} D$ respective intercept and interactive dummy variables for the structural break(s)

$d$ and $p$ are as defined above; and

$\epsilon_{1 t}, \epsilon_{2 t}$, and $\epsilon_{3 t}$ are error terms that are assumed to be white noise with zero mean, constant variance and no autocorrelation.

The modified Wald test of the Toda-Yamamoto procedure tests whether coefficients of the variables on the right-hand side of each equation are, either individually and/or jointly, significantly equal to zero. However, in conducting the modified Wald test, we need to exclude the $d^{\text {th }}$ lag from each equation and treat it as an exogenous variable. If this is not done, the Wald test statistic would not have its usual asymptotic Chi-square distribution (Giles, 2011).

(a) Unidirectional causality from trade openness to inflation is indicated if the estimated coefficients of the lagged open $_{t}$ in equation 1 are statistically different from zero (or 
$\sum_{j=1}^{p+d} \gamma_{1 j}$ open $_{t-j} \neq 0$, treating the open lag $d$ as an exogenous variable) and the set of estimated coefficients of the lagged infl in equation 2 are not statistically different from zero (or $\sum_{j=1}^{p+d} \gamma_{2 j}$ infl $l_{t-j}=0$, treating infl lag $d$ as an exogenous variable). In this case we can conclude that trade openness Granger causes inflation and not vice versa.

(b) A unidirectional causality from inflation to trade openness is indicated if the estimated coefficients of the lagged infl $_{t}$ in equation 2 are statistically different from zero (or $\sum_{j=1}^{p+d} \gamma_{2 j}$ infl $l_{t-j} \neq 0$, treating infl lag $d$ as an exogenous variable) and the set of estimated coefficients of the lagged open $n_{t}$ in equation 1 are not statistically different from zero (or $\sum_{j=1}^{p+d} \gamma_{1 j}$ open $_{t-j} \neq 0$, treating the open lag $d$ as an exogenous variable). In this case, we can conclude that inflation Granger causes trade openness and not vice versa.

(c) Feedback, or bi-directional causality, is achieved when the sets of open and $_{\text {infl }}$ coefficients are statistically significantly different from zero in both equations 1 and 2 . In this case, we can conclude that inflation Granger causes trade openness and trade openness Granger causes inflation.

(d) Independence is suggested when the sets of open and $_{\text {infl }}$ coefficients are not statistically significant in both equations 1 and 2 . In this case, we can conclude that inflation does not Granger cause trade openness and trade openness does not Granger cause inflation.

\section{Data}

All our variables are expressed in natural logarithms in order to include the proliferate effect of time series and to reduce the problem of heteroscedasticity (Gujarati, 2003). The data on all variables, except for CPI, were obtained from the World Banks's World Development Indicators. Data on CPI were obtained from monthly bulletins of the Central Statistics Office of Zambia. The study uses annual time series data from 1985 to 2015.

The analysis was done using the econometric software Stata 13 and Eviews 9.5. Unit root tests and determination of structural breaks were done in Eviews, while VAR estimation, diagnostics and Granger causality tests were done in Stata.

\section{Empirical Analysis and Results}

\subsection{Unit Root Analysis}

Table 2 below shows that results of the ADF and PP unit root tests conducted on the variables of interest in their level form. The ADF and PP results presented in table 2 show that inf, gdppc, and $m s$ are non-stationary at 5 percent level of significance regardless of whether a constant or a constant and a trend are included in the models. For open, the ADF and PP results are conflicting. On one hand, the ADF results show that open is stationary at 1 percent level of significance when either a constant or a constant and a trend is included in the model and non-stationary when both the constant and trend are not included in the model. On the other hand, the PP results show that open is non-stationary at all conventional levels of significance and regardless of whether a constant and trend are included.

Table 2: Results of the ADF and PP unit root tests on data in level form

\begin{tabular}{lcccc||ccc}
\hline \hline \multirow{2}{*}{ Variable } & \multicolumn{3}{c||}{ ADF } & \multicolumn{3}{c}{ PP } \\
\cline { 2 - 8 } infl & LL & Exo. & Test statistic & I(d) & Exo. & Test statistic & I(d) \\
\cline { 2 - 8 } infl & 0 & C & -2.181 & - & C & -2.211 & - \\
infl & 0 & C \& T & -2.128 & - & C \& T & -2.154 & - \\
open & 0 & None & $-1.716^{* * *}$ & - & None & $-1.777^{* * *}$ & - \\
& 8 & C & $-4.847^{*}$ & $\mathrm{I}(0)$ & C & -0.053 & -
\end{tabular}




\begin{tabular}{lllll||lcl} 
open & 8 & C \& T & $-4.374^{*}$ & $\mathrm{I}(0)$ & C \& T & -1.250 & - \\
open & 6 & None & -3.327 & - & None & 0.872 & - \\
gdppc & 2 & C & -1.34 & - & C & -1.457 & - \\
gdppc & 0 & C \& T & 0.35 & - & C \& T & 0.35 & - \\
gdppc & 2 & None & -0.195 & - & None & -0.483 & - \\
$m s$ & 0 & C & -2.534 & - & C & -2.420 & - \\
$m s$ & 0 & C \& T & $-3.469^{* \star *}$ & - & C \& T & $-3.448^{* \star *}$ & - \\
$m s$ & 0 & None & $-1.839^{* \star *}$ & - & None & $-1.839^{* \star *}$ & - \\
\hline \hline
\end{tabular}

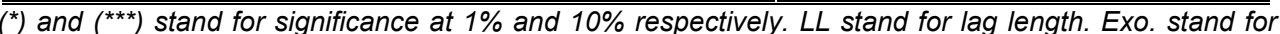
exogenous components included in the ADF and PP models: C for constant, C \& $T$ for constant and trend, and none when a constant and trend are not included.

The results presented in table 3 below show that infl and $m s$ are integrated of order one. The ADF and PP give conflicting results for gdppc and open. On one hand, the ADF indicates that open is integrated of order one when both the constant and trend are absent. On the other hand, the PP test shows that open is integrated of order two when a constant, and a constant and a trend are included in the model. When both the constant and trend are absent in the model, the PP test shows that open is integrated of order one. For the $g d p p c$, the PP test shows that the variable is integrated of order one. The ADF indicates that when a constant is included in the model, gdppc is integrated of order two. When both a constant and a trend are included in the model, the ADF shows that $g d p p c$ is integrated of order one. The same result is obtained when both the constant and trend are excluded from the model.

Table 3: Results of the ADF and PP unit root tests on data in first difference form

\begin{tabular}{|c|c|c|c|c|c|c|c|}
\hline \multirow{2}{*}{ Variable } & \multicolumn{4}{|c|}{ ADF } & \multicolumn{3}{|c|}{ PP } \\
\hline & LL & Exo. & Test statistic & I(d) & Exo. & Test statistic & I(d) \\
\hline$\Delta i n f l$ & 0 & C & $-6.677^{*}$ & 1 & C & $-6.681^{*}$ & 1 \\
\hline$\Delta i n f l$ & 0 & $C \& T$ & $-6.616^{*}$ & 1 & $C \& T$ & $-6.609^{*}$ & 1 \\
\hline$\Delta \operatorname{infl}$ & 0 & None & $-6.747^{*}$ & 1 & None & $-6.75^{\star}$ & 1 \\
\hline sopen & - & C & - & - & C & $-2.844^{\star \star \star}$ & 2 \\
\hline Dopen & - & $C \& T$ & - & - & $C \& T$ & -2.726 & 2 \\
\hline Dopen & 10 & None & $-3.148^{\star *}$ & 1 & None & $-2.881^{*}$ & 1 \\
\hline$\Delta g d p p c$ & 1 & C & -2.534 & 2 & C & $-7.26^{\star}$ & 1 \\
\hline$\Delta g d p p c$ & 0 & $C \& T$ & $-9.054^{*}$ & 1 & $C \& T$ & $-8.710^{*}$ & 1 \\
\hline$\Delta g d p p c$ & 1 & None & $-2.565^{\star *}$ & 1 & None & $-7.319^{*}$ & 1 \\
\hline$\Delta m s$ & 0 & C & $-8.910^{*}$ & 1 & C & $-10.389^{*}$ & 1 \\
\hline$\Delta m s$ & 0 & $C \& T$ & $-8.918^{*}$ & 1 & $C \& T$ & $-11.132^{*}$ & 1 \\
\hline$\Delta m s$ & 0 & None & $-8.925^{\star}$ & 1 & None & $-10.004^{*}$ & 1 \\
\hline
\end{tabular}

$\left.\left({ }^{*}\right),{ }^{* *}\right)$ and $\left(^{* *}\right)$ stand for significance at $1 \%, 5 \%$ and $10 \%$ respectively. LL stand for lag length. Exo. stand for exogenous components included in the ADF and PP models: $C$ for constant, $C \& T$ for constant and trend, and none when a constant and trend are not included.

The results in table 4 indicate that infl is integrated of order one at $1 \%$ level of significance regardless of the trend and break specifications included in the model. open is integrated of order zero at $1 \%$ level of significance regardless of the trend and break specifications included in the model. The results for $g d p p c$ and $m s$ are mixed depending on the trend and break specifications included in the model. For $g d p p c$, the results show that the variable is integrated of order one at $1 \%$ level of significance when a trend and intercept are included for trend specification and an intercept, and a trend and an intercept are considered for break specification. On the other hand, when only an intercept is considered for both trend and break specifications, the results show that $g d p p c$ is integrated of order zero at $1 \%$ level of significance. For $m s$, the results show that the variable is integrated of order zero at $1 \%$ level of significance when a trend and intercept have been included for trend specification and an intercept, and a trend and an intercept are considered for break specification. On the other hand, when only an intercept is considered for both trend and break specifications, the results show that $m s$ is integrated of order one at $1 \%$ level of significance. 
Table 4: Results of the PV unit root tests on data in level and first difference forms

\begin{tabular}{lc||c||cc||ccc}
\hline \hline \multirow{2}{*}{ Variable } & \multicolumn{2}{c||}{ Specification } & \multicolumn{2}{c||}{ Level } & \multicolumn{3}{c}{$\mathbf{1}^{\text {st }}$ Difference } \\
\cline { 2 - 7 } infl & TS & BS & BD & t-stat & BD & t-stat & I(d) \\
infl & I & I & 1992 & -3.53 & 1992 & $-8.43^{*}$ & 1 \\
infl & T and I & I & 1984 & -3.33 & 1992 & $-8.69^{*}$ & 1 \\
open & T and I & T and I & 1988 & -4.71 & 1994 & $-8.39^{*}$ & 1 \\
open & I & I & 2006 & $-6.78^{*}$ & - & - & 0 \\
open & T and I & I & 2006 & $-6.65^{*}$ & - & - & 0 \\
gdppc & T and I & T and I & 1992 & $-6.25^{*}$ & - & - & 0 \\
gdppc & I & I & 1989 & $-5.02^{*}$ & - & - & 0 \\
gdppc & T and I & I & 2003 & -1.62 & 1974 & $-10.99^{*}$ & 1 \\
ms & T and I & T and I & 1993 & -4.03 & 1981 & $-11.77^{*}$ & 1 \\
ms & I & I & 1993 & $-4.39^{* * *}$ & 1994 & $-9.97^{*}$ & 1 \\
ms & T and I & I & 1993 & $-7.36^{*}$ & - & - & 0 \\
\hline \hline
\end{tabular}

$\left(^{*}\right)$ and $\left(^{* * *}\right)$ stand for significance at $1 \%$ and $10 \%$ respectively. TS stand for trend specific and BS stand for break specific. BD and t-stat stand for break date and t-statistic respectively. I and $T$ stand for intercept and trend respectively.

We have presented the unit root tests for all the variables using the ADF, PP, and PV tests. The $A D F$ and PP tests do not take into account structural breaks. The PV unit root test take into account structural breaks. Therefore in cases where we have conflicting results between the ADF and/or PP tests, and the PV test, we gave priority to the results from the PV test. For this reason, we can conclude the highest order of integration, and hence the dmax, among all the variables is one.

\subsection{Determining the break date(s) in the entire model}

Since most, if not all, time series variables are plagued with structural changes, it is important to incorporate break dates in regressions. As we have already stated, if one estimates a regression without taking into account structural changes, then one risks committing misspecification errors whose consequences are discussed by Gujarati (2003). In this paper, we use the Bai (1997) and Bai and Perron $(1998,2003 a)$ sequential testing procedures to check for the break dates in our entire model; that is, taking all the variables together.

Table 5: Bai-Perron multiple breakpoint test

\begin{tabular}{ccccc}
\hline \hline Break test & F-statistic & Scaled F-statistic & Critical values & Break dates \\
\hline \hline 0 vs $1^{* *}$ & 23.937 & 71.810 & 13.98 & 1993 \\
1 vs $2^{\star *}$ & 6.004 & 18.013 & 15.72 & 1985 \\
2 vs $3^{\star *}$ & 6.029 & 18.088 & 16.83 & 2000 \\
3 vs 4 & 1.531 & 4.594 & 17.61 & \\
\hline \hline
\end{tabular}

${ }^{\left({ }^{* *}\right)}$ significant at 5\% level. Critical values are based on Bai and Perron (2003)

The Bai-Perron sequential test results in table 5 indicate that we rejected the null hypotheses that there are 0,1 , and 2 breakpoints in favour of the alternatives of 1,2, and 3 breakpoints at $5 \%$ level of significance, but the null hypothesis of 4 versus 3 breakpoints was not rejected. Furthermore, the test indicated that the breakpoints are 1993, 1985, and 2000.

\subsection{Diagnostic tests of the underlying VAR}

After establishing the structural break points, we ran a VAR(3) with 1993 as the structural break date. The other structural break dates determined by the Bai-Perron multiple breakpoint test (1985 and 2000) were insignificant, and hence dropped. The diagnostic tests of the $\operatorname{VAR}(3)$ are presented below. 


\subsubsection{Test for normality of residuals}

Table 6 below shows the result of Jarque-Bera test for normality of the residuals. It is evident that we failed to reject the null hypothesis of normality of residuals of each equation as well as all the equations combined at 5 percent level of significance.

Table 6: Jarque-Bera normality test result

\begin{tabular}{cccc}
\hline \hline Equation & Chi-square & df & Prob > Chi-square \\
\hline \hline infl & 0.666 & 2 & 0.71671 \\
open & 0.632 & 2 & 0.72918 \\
gdppc & 0.472 & 2 & 0.78974 \\
ms & 2.343 & 2 & 0.30987 \\
All & 4.113 & 8 & 0.84677 \\
\hline \hline
\end{tabular}

Prob and df stand for probability and degrees of freedom respectively

\subsubsection{Autocorrelation test}

Table 7 below shows Lagrange-multiplier (LM) test result for residual autocorrelation. The test revealed that at first, second and up to the sixth lags, we failed to reject the null hypothesis of no autocorrelation among the residuals at 5 percent level of significance. Thus, we concluded that there was no autocorrelation among the residuals in the model.

Table 7: LM test result for serial correlation

\begin{tabular}{cccc}
\hline \hline Lag & Chi-square & df & Prob > Chi-square \\
\hline \hline 1 & 23.2736 & 16 & 0.10662 \\
2 & 22.3479 & 16 & 0.13231 \\
3 & 19.9951 & 16 & 0.22044 \\
4 & 17.5010 & 16 & 0.35391 \\
5 & 24.5142 & 16 & 0.07886 \\
6 & 12.5030 & 16 & 0.70869 \\
\hline \hline
\end{tabular}

Prob and df stand for probability and degrees of freedom respectively

\subsubsection{Stability test of the VAR}

Figure 1 below shows the result of the stability test of the underlying VAR(3) model. It is evident that as required, all the eigenvalues lie inside the unit circle. This implies that the estimated model is dynamically stable.

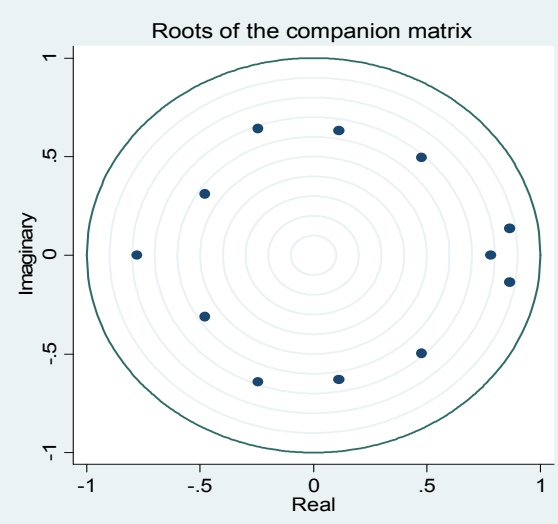

Figure 1: Eigenvalue stability condition for the estimated VAR(3) 


\subsubsection{Toda-Yamamoto Granger causality test results}

Since the estimated VAR(3) passed all the diagnostic tests, we re-estimated the VAR by including the $d \max =1$; that is, we estimated a $\operatorname{VAR}(3+d \max )$, or simply $\operatorname{VAR}(4)$. The additional lag $d \max =1$ was included in the model as an exogenous variable together with the respective dummies created using the break date of 1993. Based on the results of the VAR(4), we performed the Granger causality test using the modified Wald test. The results in table 8 show that bidirectional causality exists between inflation and trade openness. This means that trade openness Granger causes inflation, and inflation Granger causes trade openness. The estimated VAR models shows a positive relationship between inflation and trade openness implying that an increase in trade openness leads to an increase in inflation and that a rise in the inflation rate leads to an increase in trade openness. This bidirectional positive relationship in the Zambian case is contrary to Romer's (1993) hypothesis that there is a negative relationship between inflation and trade openness, but consistent with Ashra (2002) for Bangladesh, and Zakaria (2010) and Munir and Kiani (2011) both for Pakistan.

This result suggests that the observed trend in consumer prices in Zambia cannot only be attributed to the economy's internal problems but also the influences of developments on the international market. The positive relationship between trade and openness is rationalized by the fact that Zambia is a developing country and mainly depends on imports for most of its consumable goods. As such, we can conclude that a considerable proportion of the observed changes in the consumer price index is attributable to the changing price level of imported goods - imported inflation. Imported inflation is determined by both the corresponding conditions on world markets, which establishes the prices of the goods we import in foreign currency, and by the value of the Zambian Kwacha in relation to other currencies. Our finding stresses the point that understanding the consequences of international trade for domestic inflation is extremely important for central banks. Besides, this reason, Zakaria (2010) argues that authorities tend to lose their ability to control inflation using monetary and fiscal policies as the economy opens up.

On other variables, we find a bi-directional relationship between inflation and economic growth, and a unidirectional relationship running from inflation to money. The result of table 8 also shows the following: first, trade openness, economic growth, and money supply jointly Granger cause inflation. Secondly, inflation, economic growth, and money supply jointly Granger cause trade openness. Thirdly, inflation, trade openness, and money supply jointly Granger cause economic growth. Lastly, inflation, trade openness, and economic growth jointly Granger cause money supply.

Table 8: Granger causality test results

\begin{tabular}{ccccc}
\hline \hline Equation & Excluded & Chi-square & df & Prob > Chi-square \\
\hline \hline infl & open & 12.596 & 3 & 0.006 \\
infl & gdppc & 5.6521 & 3 & 0.0130 \\
infl & ms & 0.3344 & 3 & 0.953 \\
infl & All & 54.235 & 9 & 0.000 \\
open & infl & 12.846 & 3 & 0.005 \\
open & gdppc & 9.0237 & 3 & 0.029 \\
open & $m s$ & 0.0465 & 3 & 0.998 \\
open & All & 46.596 & 9 & 0.000 \\
gdppc & infl & 17.006 & 3 & 0.001 \\
gdppc & open & 18.185 & 3 & 0.000 \\
gdppc & $m s$ & 32.264 & 3 & 0.000 \\
gdppc & All & 185.55 & 9 & 0.000 \\
ms & infl & 24.249 & 3 & 0.000 \\
ms & open & 75.377 & 3 & 0.000 \\
ms & gdppc & 27.767 & 3 & 0.000 \\
ms & All & 186.75 & 9 & 0.000 \\
\hline \hline
\end{tabular}

Prob and df stand for probability and degrees of freedom respectively. 


\section{Conclusion}

This study sought to investigate the causal relationship between inflation and trade openness in Zambia. The results obtained indicate a bi-directional causality between inflation and trade openness implying that openness Granger causes inflation and inflation Granger causes openness. We also find that trade openness has a significant positive effect on inflation. This result refutes Romer's (1993) hypothesis that there is a negative relationship between inflation and openness. This result can be due to the fact that Zambia is a small open economy that relies on imports for most of its consumption and production needs. Therefore, the observed inflation in Zambia cannot be attributed to the economy's internal problems alone, but also the price increases on the international market. Moreover, as the economy opens up, the authorities find it difficult to put inflation under control using fiscal and monetary policies (Zakaria 2010).

The results of this study are important for monetary policy makers in Zambia, especially after adopting inflation targeting as the framework for monetary policy formulation. The central bank (Bank of Zambia) should be wary of relying on Romer's (1993) hypothesis as guiding principle in controlling inflation in a country that is outward looking. Instead, it should pay attention to changes in the price levels of imports on the international markets, especially Zambia's trading partners. This implies that in times when the price level of imports is high, the Bank should anticipate high inflation and protect the domestic price level from rising by pursuing contractionary monetary policy.

\section{References}

Ashra, S. (2002). Inflation and openness: A study of selected developing economies. Indian Council for Research on International Economic Relations. Working Paper, 84.

Bai, J. (1997). Estimating multiple breaks one at a time. Econometric Theory, 13 (3), 315-352.

Bai, J. and Perron, P. (1998). Estimating and testing linear models with multiple structural changes. Econometrica, 66 (1), 47-78.

Bai, J. and Perron, P. (2003a). Computation and analysis of multiple structural change models. Journal of Applied Econometrics, 18 (1), 1-22.

Banerjee, A., Lumsdiane, R.L. and Stock, J. (1992). Recursive and sequential tests of the unit-root and trendbreak hypotheses. Journal of Business and Economic Statistics, 10 (3), 271-87.

Binici, $\quad$ M., Cheung, W. Y. and Lai, S. K. (2012). Trade openness, market competition, and inflation: Some sectoral evidence from OECD countries. CESifo, Working Paper, 3690.

Bleaney, M. (1999). The disappearing openness inflation relationship: A cross-country analysis of inflation rates. International Monetary Fund, Working Paper, 161.

Dickey, D. A. and Fuller, W. A. (1979). Distribution of the estimators for autoregressive time series with a unit root. Journal of the American Statistical Association, 74 (366), 427-431.

Giles, D. (2011). Testing for Granger causality. Econometrics beat: Dave Gile's blog. Available at: http://davegiles.blogspot.com/2011/04/testing-for-granger-causality.html.

Gujarati, D. N. (2003). Basic Econometrics (4th ed.). New York, NY: McGraw-Hill.

Gruben, W. C. and McLeod, D. (2004). The openness-inflation puzzle revisited. Applied Economics Letters.11 (8), 465-468.

International Monetary Fund. (2000). World Economic Outlook: Recessions and Recoveries. Washington D.C: International Monetary Fund. Retrived from http://www.imf.org/external/pubs/ft/weo/2000/02/pdf/append.pdf

lyoha, M. A. (1973). Inflation and openness in less developed economies: A cross-country analysis. Journal of Economic Development and Cultural Change, 22 (1), 31-38.

Jin, J. (2000). Openness and growth: An interpretation of empirical evidence from East Asian countries. Journal of International Trade and Economic Development, 9 (1), 5-17.

Kim, M. and Beladi, H. (2005). Is free trade deflationary? Economic Letters, 89 (3), 343-349.

Lane, P. (1997). Inflation in open economies. Journal of International Economics, 42 (3-4), 327-347.

Mudenda, D. (2009). Trade and industrialization policies experienced from Zambia. Industrial Policy Thematic Working Group, Southern African Development Research Network.

Munir, S., Hasan, H. and Muhammad, M. (2015). The effect of trade openness on inflation: Panel data estimates from selected Asian economies. Southeast Asian Journal of Economics, 3 (2), 23-42.

Munir, S. and Kiani, A. K. (2011). Relationship between trade openness and inflation: Empirical evidences from Pakistan. The Pakistan Development Review, 50 (4), 853-876.

Ndulo, M. and Mudenda, D. (2004). Trade policy reform and adjustment in Zambia. United Nations Conference on Trade and Development Zambia Study. 
Nunziata, L. and Bowdler, C. (2006). Trade openness and inflation episodes in the OECD. Journal of Money, Credit, and Banking, 38 (2), 553-563.

Perron, P. (1989). The great crash, the oil price shock, and the unit root hypothesis. Econometrica, 57, 13611401.

Perron, P. and Vogelsang, T. J. (1992). Nonstationarity and level shifts with an application to purchasing power parity. Journal of Business and Economic Statistics, 10 (4), 301-320.

Phillips, P. C. B. and Perron, P. (1988). Testing for a unit root in time series regression. Biometrika, 75 (2), 335346.

Rogoff, K. (1985). Can international monetary policy cooperation be counterproductive? Journal of International Economics, 18, 3 (4), 99-217.

Romer, D. (1993). Openness and inflation: Theory and evidence. Quarterly Journal of Economics, 108(4), 869903.

Romer, P. M. (1989). Human capital and growth: Theory and evidence. National Bureau of Economic Research, Working Papers 3173.

Seshamani, V. (1992). The economic policies of Zambia in the 1980s: Towards structural transformation with a human focus. In: Gornia, G. A. et al. (ed.) Africa's recovery in the 1990s. New York: St Martins.

Temple, J. (2002). Openness, inflation and the Phillips curve: A puzzle. Journal of Money, Credit and Banking, 34 (2), 450-68.

Terra, C.T. (1998). Openness and inflation: A new assessment. Quarterly Journal of Economics, 113 (2), 641648

Toda, H.Y. and Yamamoto, H. (1995). Statistical inference in vector autoregressions with possibly integrated processes. Journal of Econometrics, 66 (1-2), 225-250.

Triffin, R. and Grudel, H. (1962). The adjustment mechanism to differential rates of monetary expansion among the Countries of the European Economic Community. Review of Economics and Statistics, 44(11), 486491.

Umar, M. and Dahalan, J. (2015). Evidence on real exchange rate-inflation causality: An application of the Toda-Yamamoto dynamic Granger causality test. International Business Management, 9 (5), 666-675.

United Nations Conference on Trade and Development. (2004). Development and globalization: Facts and figures. New York and Geneva: United Nations.

World Bank Zambia. (2008). Accelerating and sharing growth through improved competitiveness. Lusaka Zambia.

Yanikkaya, H. (2003). Trade openness and economic growth: A cross-country empirical investigation. Journal of Development Economics, 72(1), 57-89.

Zakaria, M. (2010). Openness and inflation: Evidence from time series data. Doğuş Üniversitesi Dergisi, 11 (2), 313-322.

Zivot, E. and Andrews, K. (1992): Further evidence on the great crash, the oil price shock, and the unit root hypothesis. Journal of Business and Economic Statistics, 10 (10), 251-70. 